УДК 504.064

DOI: https://doi.org/10.26642/ten-2021-2(88)-55-62

А.Г. Ткачук, к.т.н., доц.

А.В. Коваль, к.т.н., доц.

А.А. Гуменюк, к.т.н., доц.

І.В. Крижанівська, к.т.н., доц.

В.О. Левчук, магістр

Державний університет «Житомирська політехніка»

\title{
Експериментальні дослідження автоматизованої системи моніторингу наявності шкідливих та вибухонебезпечних газів на базі БпЛА
}

У статті розглянуто нову автоматизовану систему моніторингу наявності шкідливих та вибухонебезпечних газів на базі безпілотного літального апарата. Встановлено, щчо така система є необхідною для попередження про можливі загрози вибухів чи отруєння газами, проведення рятувальних робіт тощо. Описано розроблену конструкцію безпілотного літального апарата, яка складається з рами, безщіткових двигунів, модулів електронного контролю швидкості, контрольної плати, інерціальної навігаційної системи і модуля прийому та передачі. Зазначено функиіональну схему автоматизованої системи моніторингу наявності шкідливх та вибухонебезпечних газів на базі безпілотного літального апарата. Проведено статичний експеримент розробленої системи, основною ідеєю проведення якого було вивчення залежності відстані джерела газу до вимірювальної системи та покази концентрації газу. Досліджено датчики газів MQ-5 та MQ-9. Також наведено результати статичного експерименту на відкритому повітрі, де досліджено залежність вимірюваної концентрації газу від відстані між джерелом газу та вимірювальним модулем. Цей експеримент демонструє кореляцію між відстанню від джерела газу та виміряним рівнем концентрації газу. Проаналізовано результати льотних експериментів розробленої автоматизованої системи моніторингу, які показують кореляцію між відстанню від джерела газу та виміряним рівнем концентрації газу під час автоматичного польоту.

Ключові слова: робототехніка; безпілотний літальний апарат; моніторинг; екологія.

Актуальність теми. Інтерес у використанні безпілотних літальних апаратів (БпЛА), або ж простіше - дронів, у багатьох різноманітних сферах діяльності людини не припиняє зростати. БпЛА мобільний, автономний апарат, який є різновидом літальних роботів 3 можливістю передачі часткового або повного управління людині та запрограмований на виконання певних завдань, таких як: спостереження, дистанційне зондування, картографія, пошук i порятунок тощо. Одним 3 найперспективніших напрямів цивільних застосувань БпЛА є моніторинг витоків газу, оскільки якість повітря безпосередньо впливає на здоров'я та якість життя людини. Це спричиняє велику кількість досліджень у цій галузі, які умовно можна поділити на моніторинг якості внутрішнього та зовнішнього повітря. Серед яких наразі моніторинг якості повітря у приміщенні є менш вивченою темою.

Процес пошуку та локалізації шкідливих і вибухонебезпечних газів необхідний для розвідувальнопопереджувальних робіт з метою:

- захоплення / визволення стратегічно важливих будівель, ліквідації ворога та попередження військовослужбовців про можливі загрози вибухів чи отруєння газами;

- проведення рятувальних робіт, евакуації цивільних мешканців у будинках, де відбувся витік газу чи вибух;

- проведення рятувальних робіт після техногенних катастроф;

- моніторингу рівня шкідливих для здоров’я людини газів (що провокують ракові та респіраторні захворювання) в околицях житлових будівель.

Сьогодні оцінка якості повітря, як показали дослідження, проводиться наземним моніторингом (роботами). Однак виконати швидкий, максимально повний збір даних поблизу джерел забруднення всередині будівлі дуже складно. Хоча б через те, що наземні роботи не можуть піднятися по сходах або подолати перешкоди $з$ уламків, що утворилися після вибуху. Тому використання БпЛА для виконання таких робіт є актуальним та доцільним.

В умовах складної ситуації на Сході України доцільною є розробка приладів та систем, які будуть допомагати військовослужбовцям під час проведення операцій та попереджувати їх про існуючі для життя загрози. Також сьогодні перед Міністерством Оборони України гостро стоїть проблема підвищення обороноздатності України за умови обмеженості ресурсів. Нова автоматизована система

(C) А.Г. Ткачук, А.В. Коваль, А.А. Гуменюк, І.В. Крижанівська, В.О. Левчук, 2021 
моніторингу на основі БпЛА складається із комплектуючих, які знаходяться у вільному продажі в Україні та має невисоку собівартість.

Аналіз останніх досліджень та публікацій, на які спираються автори. У країнах Свросоюзу дуже активно розробляють безпілотну авіаційну техніку, проте використовується вона в основному для розвідувальних та бойових операцій на відкритих місцевостях.

У [1-6] запропоновано стаціонарну систему моніторингу, яка складається з базової станції 3 підключенням до Інтернету та автономними вузлами. В умовах проведення розвідувальнопопереджувальних операцій в аварійних будівлях така система використовуватися не може, оскільки потребує безпосереднього встановлення та налагодження на місці проведення моніторингу.

Аналоги автоматизованої системи на БпЛА, що проєктується, описані у [7-8]. Вказана система здатна виконувати пошук газів за різними сценаріями забруднення та встановлена на гексакоптер. Результати експериментів показали, що недоліком такої системи $\epsilon$ те, що вона використовує GPS-сигнал та неспроможна працювати у закритих приміщеннях, куди цей сигнал не поступає.

Аналоги $[9,10]$ мають основне джерело живлення для БпЛА та системи - сонячну енергію, що не $\epsilon$ надійним в умовах використання під час бойових розвідувальних операцій.

Розроблена автоматизована система моніторингу наявності шкідливих та вибухонебезпечних газів в околицях та всередині споруд житлового й нежитлового призначення на основі БпЛА буде легкою в керуванні та зручною для аналізу отриманих результатів.

Метою статті $\epsilon$ дослідження особливостей конструкції автоматизованої системи моніторингу наявності шкідливих та вибухонебезпечних газів на базі безпілотного літального апарату й проведення експериментальних досліджень цієї системи.

Викладення основного матеріалу. Науковцями Державного університету «Житомирська політехніка» розроблено нову автоматизовану систему моніторингу наявності шкідливих та вибухонебезпечних газів на базі БпЛА. Система може бути встановлена на БпЛА будь-якого типу. Згідно 3 критерієм «ефективність - вартість», нова система буде найкращою серед відомих аналогів.

Базова архітектура БпЛА (рис. 1) складається з: рами; безщіткових двигунів (Braushless motor); модулів електронного контролю швидкості (ESC, укр.: ЕКШ); контрольної плати (Control Board); інерціальної навігації системи (INS) і модуля прийому та передачі (Antenna). Безщіткові двигуни забезпечують механічну енергію, необхідну для обертання гвинтів. Обертання двигуна регулюється за допомогою ЕКШ для кожного двигуна; ЕКШ керується сигналом імпульсної модуляції (PWM, укр.: ПЗМ).

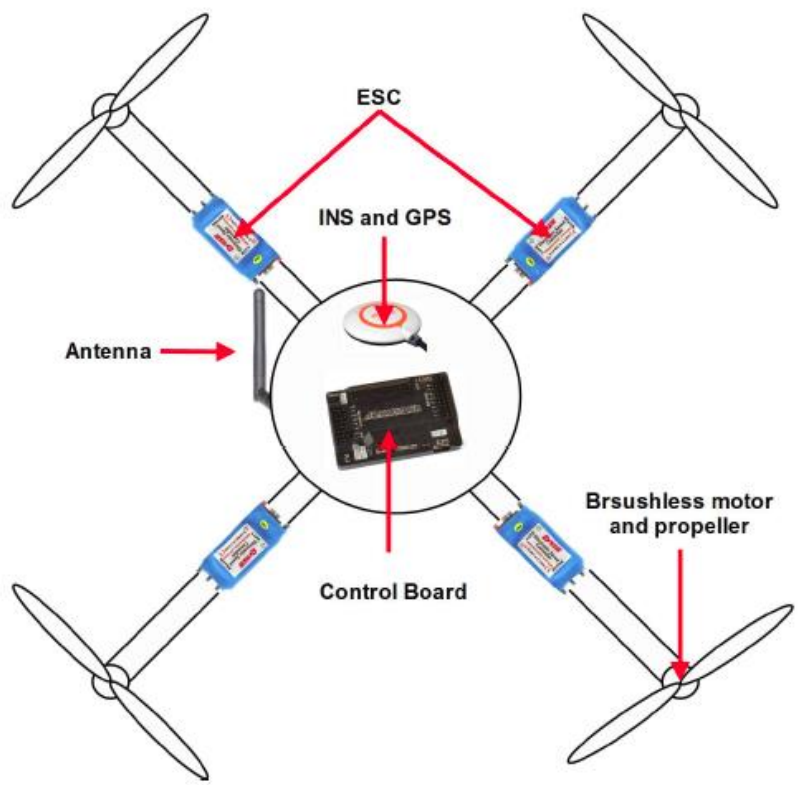

Рис. 1. Базова архітектура БпЛА

Змінюючи значення робочого циклу, можна збільшити і зменшити кутову швидкість гвинта. Таким чином, дрон виконує рухи по кутам никання, крену, тангажу та тязі, переміщується уздовж поздовжньої та горизонтальної осей. Для підвищення стабільності польоту БпЛА оснащується IНС, яка складається 3 тривісного акселерометра, тривісного гіроскопа та тривісного магнітометра для вимірювання прискорень, кутових швидкостей та магнітних значень відповідно. Отримавши вимірювання 3 IHC, можна оцінити трьохосьові вимірювання кутів Ейлера. Ці кути потім використовуються для керування орієнтацією літака під час польоту. Вимірювання орієнтації дрона грунтуються на основі значень 
прискорення та магнітного поля, на які суттєво впливає шум. 3 цієї причини для зменшення впливу шуму на вимірювання орієнтації використовуються алгоритми злиття даних, які враховують значення кутових швидкостей, надані гіроскопом. Прикладом алгоритмів злиття даних є розширений фільтр Калмана (EKF). Ці алгоритми є обчислювально інтенсивними, тому вони можуть бути важкими для виконання на платі керування. Через це інерційні вимірювальні модулі (IBM) з вбудованими процесорами для виконання алгоритмів злиття даних є хорошим рішенням. VN-100 SMD від VectorNAV - це високопродуктивний IBM і базова система орієнтації та курсу, яка включає в себе 32-розрядний мікропроцесор для обчислення вимірювань орієнтації в режимі реального часу за допомогою алгоритму EKF.

Отже, виокремимо базові елементи для розроблюваного БпЛА. Чотири основні компоненти цієї підсистеми - це рама, двигуни, електронні регулятори швидкості та акумулятор. Рама на базі DJI F450 Flamewheel. Вона виготовлена 3 PA6 + 30GF нейлону 6/6, армованого склопластиком, що забезпечує міцність і довговічність. Плата РСВ високої міцності була включена в дизайн апарату, щоб забезпечити централізований розподіл електроенергії. Використовувані двигуни з оцінкою 980 кВ з максимальним струмом 17,2 А під статичним навантаженням. 3 напругою 11,1 вольт, що постачається від акумулятора. Двигуни здатні забезпечити 960 г тяги при максимальній швидкості обертання двигуна. Електронні регулятори швидкості на 25 А забезпечать достатню потужність та струм для двигунів, зберігаючи при цьому прийнятний буфер між фактичним поточним споживанням двигунів та максимальним струмом за допомогою ЕКШ. Джерелом живлення компонентів БпЛА $є$ літій-полімерний (LiPo) акумулятор, що видає напругу $11,1 \mathrm{~B}$.

Важливо зазначити, що безпілотні літальні апарати не можуть літати без обмежень. Відповідно до чинних нормативно-правових актів 3 авіаційної безпеки, обмежується їх використання в комерційних, дослідницьких та приватних застосунках. Наприклад, в більшості країн вимагається, щоб БпЛА керувався сертифікованим оператором. Це підвищує безпеку, але є затратним та трактує, хто може легально проводити операції на БпЛА. Це, в свою чергу, безпосередньо впливає на частоту, якість та тип досліджень атмосфери, які можуть бути проведені.

Принцип дії запропонованої автоматизованої системи зображено у вигляді функціональної схеми на рисунку 2.
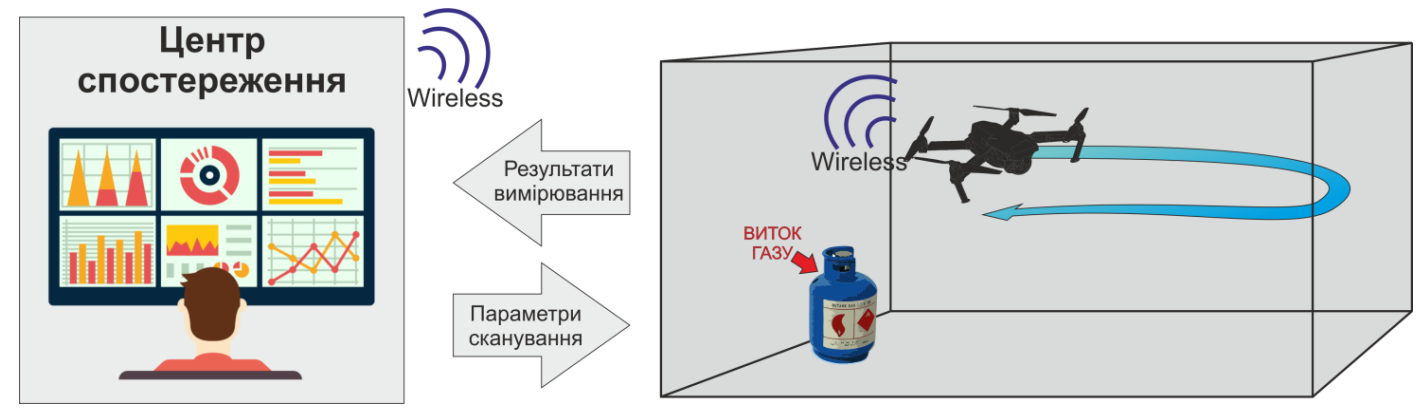

Рис. 2. Функиіональна схема автоматизованої системи пошуку газів

Всі експерименти, які були виконані в цій частині, проводилися з використанням платформи БпЛА 3 підключеним газоаналізатором.

Статичний експеримент. Основною ідеєю проведення статичного експерименту є вивчення залежності відстані джерела газу до вимірювальної системи та покази концентрації газу.

Було проведено статичні вимірювання в лабораторії ДП «Житомирстандартметрологія» 3 вимірювання сталої концентрації метану. Отримані результати для датчиків МQ-5 (рис. 3) та MQ-9 (рис. 4) зображено на відповідних графіках.

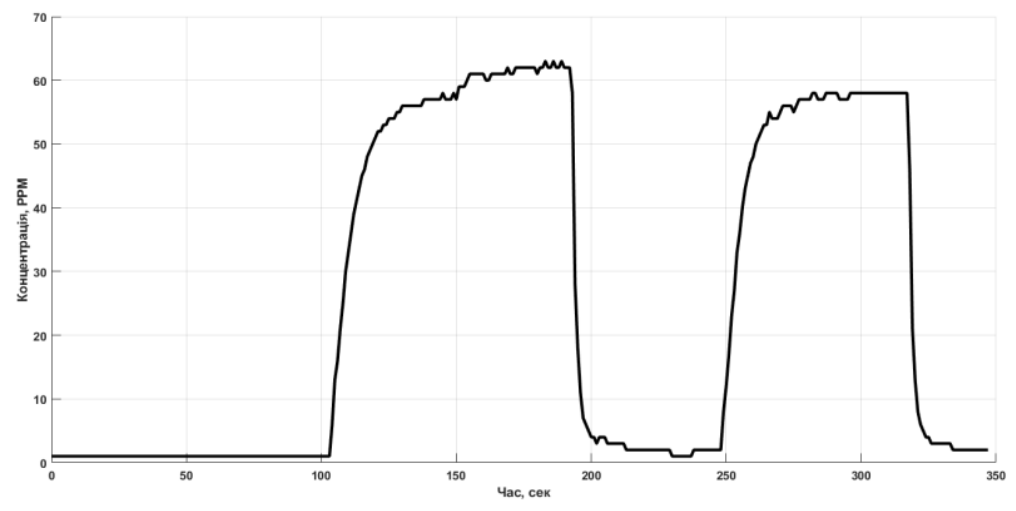

Рис. 3. Графік зміни конценттрації метану в часі для датчика MQ-5 
3 першого графіка видно, що в першому вимірюванні значення виходить на поточне за 70 секунд, але пікова концентрація не $є$ рівномірною і коливається між 61 та $63 \mathrm{ppm}$. Повернення у вихідне значення відбувається за 38 секунд.

У другому вимірюванні спостерігаємо більш рівномірне пікове значення в 58 ррm. Вихід від номінальної до пікової концентрації відбувається за 60 секунд, що на 14 \% швидше за попередній, а повернення у початкове значення за 18 секунд, що на 53 \% швидше.

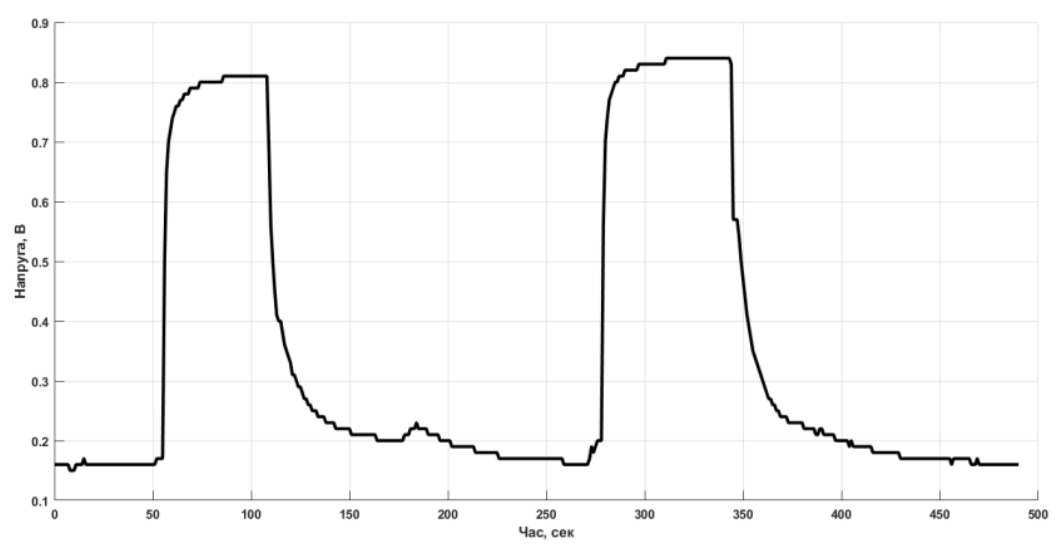

Рис. 4. Графік зміни вихідної напруги в часі для датчика MQ-9

3 другого графіка можна зрозуміти, що в першому вимірюванні значення напруги виходить на поточне за 36 секунд і швидко фіксується на значенні $0,81 \mathrm{~B}$. Але помітним недоліком цієї установки $\epsilon$ те, що повернення у номінальне значення відбувається досить довго - 152 секунди.

У другому вимірюванні бачимо щось схоже: швидкість стабілізації значення напруги - 41 секунда, а повернення у номінальне значення - за 128 секунд.

У кожної з установок $є$ свої переваги та недоліки. Нерівномірні пікові значення в першій установці можна пояснити шумами, які створюють надто довгі проводи-конектори, але ця проблема легко усувається мінімізацією їх довжини та екрануванням. Друга установка показала також досить непоганий результат хоча й період одного вимірювання у неї досить великий - 209 секунд проти 128 секунд у першій установці.

Отже, враховуючи всі проведені вимірювання і їх аналіз, можна зробити висновок про доцільність використання будь-якої із запропонованих установок, оскільки результати цілком відповідають необхідній швидкості реакції на зміну газового середовища.

Проведення наступного статичного експерименту (рис. 5) на відкритому повітрі, де досліджено залежність вимірюваної концентрації газу від відстані між джерелом газу та вимірювальним модулем. На першій стадії вимірювальний модуль розташовувався на відстані 100 см від джерела газу. Далі починався запис даних про концентрацію газу, після чого відкрився газовий балон, і вмикався вентилятор, що створює напрямлений вітровий потік поблизу джерела газу. Коли вимірюваний рівень газу досягав усталеного значення газовий балон закривався, і протягом деякого часу вимірювання тривало поки рівень газу не досягне нульового рівня (мінімальна вимірювана концентрація для цього типу датчика). Схема проведення експериментів показана на рисунку 5, а результати вимірів - на рисунку 6.

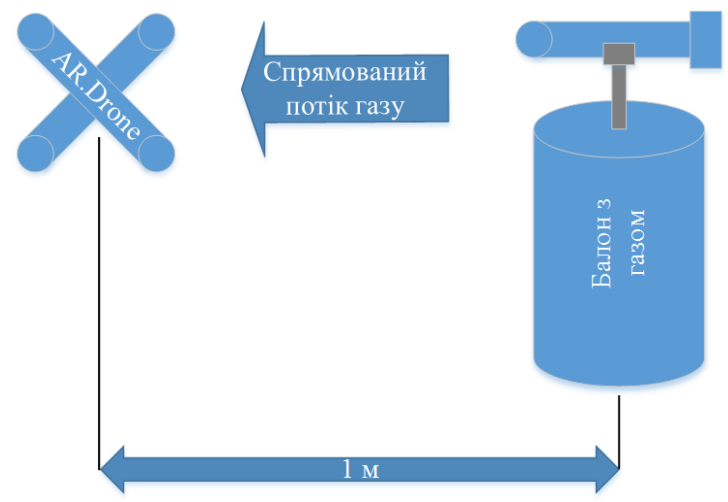

Рис. 5. Методика проведення експерименту 


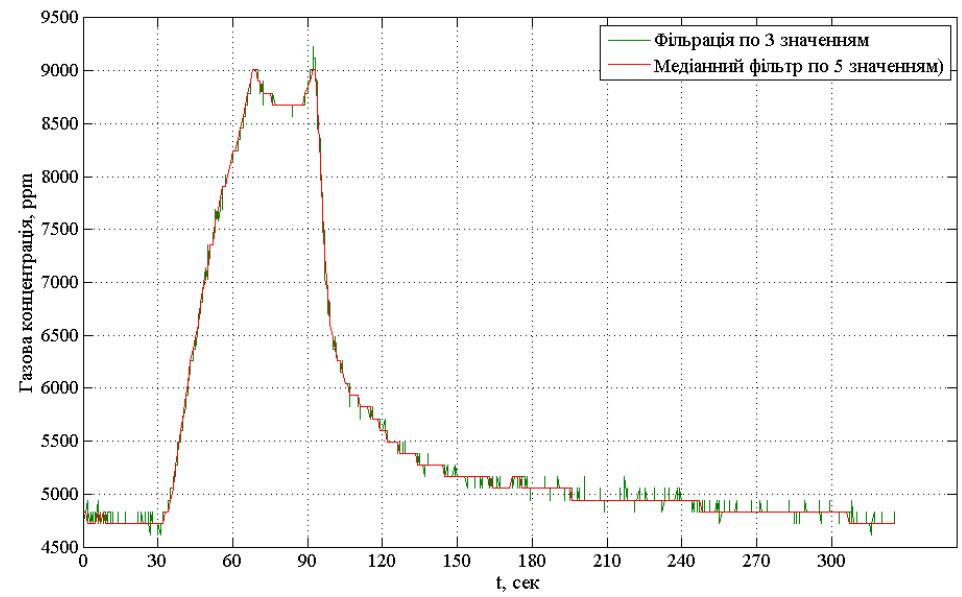

Рис. б. Вимірювання концентрації газу в лабораторних умовах на відкритому повітрі (відстань від джерела газу 1 м)

Під час проведення ще одного статичного експерименту на першому етапі вимірювальна система розташована на відстані 30 см від джерела газу і починала записувати вимірювальні параметри, після чого відкрився газовий балон, і вмикався вентилятор, що створює прямий вітровий потік поблизу джерела газу. Потім, коли вимірювання рівня газу було завершено, газовий балон закривався, і протягом деякого часу вимірювання тривало доки рівень газу не досягне позначки «стан без газу». Коли цей експеримент закінчився, наступний експеримент починався з іншої відстані. Відстані були вибрані в діапазоні 30-130 см з кроком 10 см. Після 130 см можливість виявити газ все ще присутня, але оскільки джерело газу та вимірювальної системи були розташовані на одному рівні, збільшення відстані було припинено. Техніка експериментів зображена на рисунку 7.

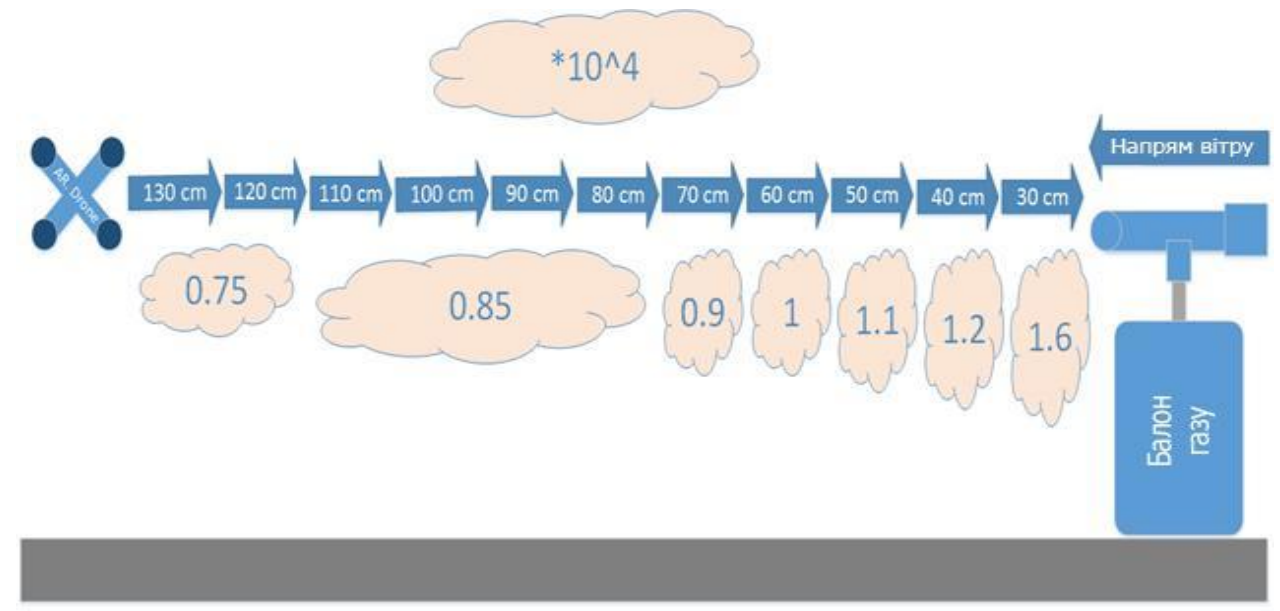

Рис. 7. Техніка проведення статичного експерименту

Статичний експеримент, що демонструє кореляцію між відстанню від джерела газу та виміряним рівнем концентрації газу, зображений на рисунку 8.

Якщо джерело газу розташовано нижче ніж вимірювальний сенсор - чутливість сенсора газу збільшується. Це викликано тому, що бутан, який використовувався для експериментів, легший за повітря. 


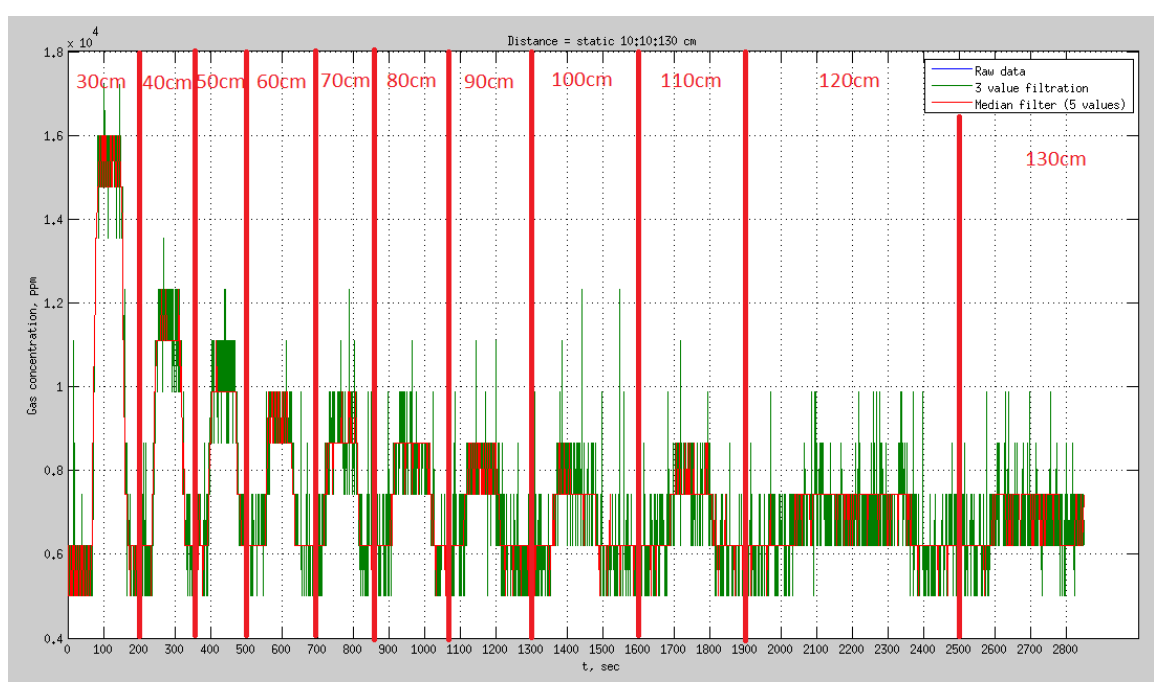

Рис. 8. Статичний експеримент, відстань: 0-130 см, крок вимірювання - 10 см $(y-$ кониентрація газу, $x-$ час )

Проведено також експериментальні виміри LPG, атмосферного повітря та $\mathrm{CO}_{2}$.

Льотний експеримент. Льотні експерименти показують кореляцію між відстанню від джерела газу та виміряним рівнем концентрації газу під час автоматичного польоту (рис. 9).

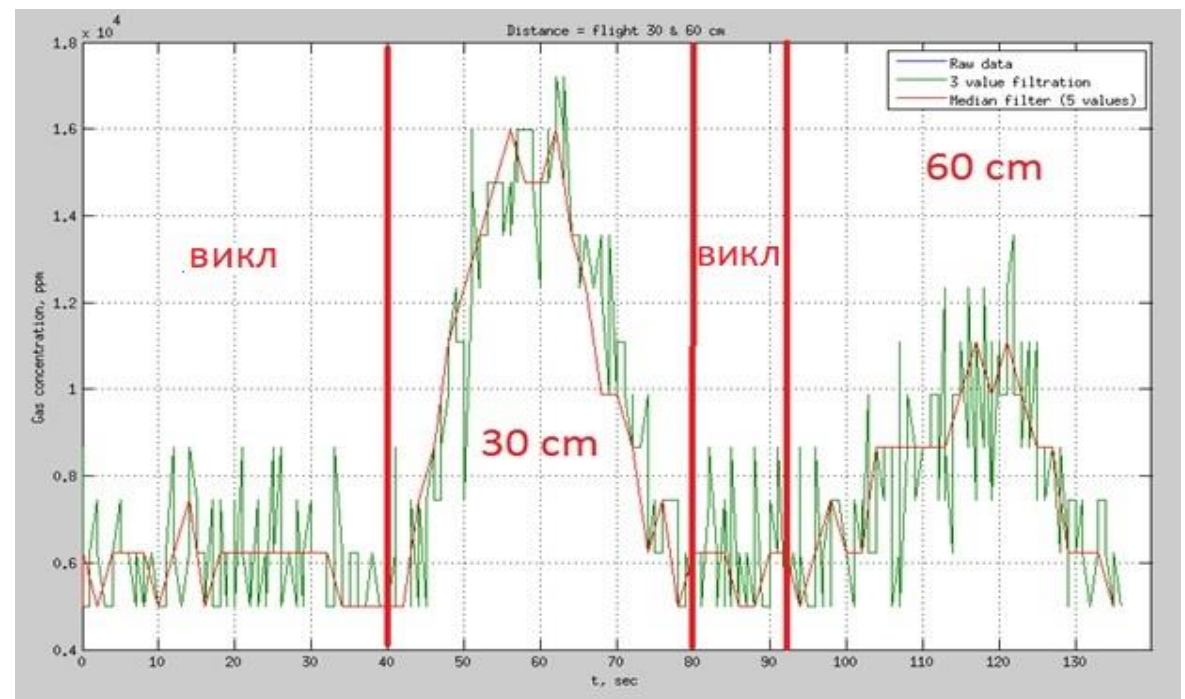

Рис. 9. Результати льотних експериментів (y-концентрація газу, $x$-час) на відстані 30 та 60 см від джерела газу

Згідно з рисунком 9 можна зауважити, що під час польоту виявлення рівня газу гірше, ніж у статичному режимі. Деякий вплив на покази вимірювань був створений пропелерами БпЛА і саме це пояснює різницю між вимірами в статичному та льотному режимах.

Висновки та перспективи подальших досліджень. Описано нову автоматизовану систему моніторингу небезпечних газів на базі БпЛА, представлено загальну функціональну схему та запропоновано методологію побудови й проведення вимірювань за допомогою такої системи. Як чутливі елементи системи пошуку та виявлення газів було обрано датчики напівпровідникового типу MQ135, MQ-5 та MQ-9, які відповідають всім необхідним вимогам для встановлення на БпЛА. Було проведено статичні експерименти з вимірювання сталої концентрації метану. На основі отриманих результатів було зроблено висновок про доцільність використання будь-якого із запропонованих датчиків для встановлення на БпЛА. У співпраці з Університетом Країни Басків (Більбао, Іспанія) було проведено експериментальні льотні випробування з вимірюванням забрудненості повітря метаном та побудови мапи газу. 
Список використаної літератури:

1. Wireless sensor network for indoor air quality monitoring / J.Lozano, J.I. Suárez, P.Arroyo et al. // Chemical Engineering. - 2012 [Electronic resource]. - Access mode : http://www.seedengr.com/documents/Wireless \%20Sensor\%20Network\%20For\%20Indoor\%20Air\%20Quality\%20 Monitoring.pdf. DOI: 10.3303/CET1230054.

2. Wireless sensor networks for indoor air quality monitoring / Tsang-Chu Yu,Chung-Chih Lin, Chun-Chang Chen et al. // Medical engineering \& physics. - 2013. - Vol. 35 (2). - P. 231-235 [Electronic resource]. - Access mode : http://www.sciencedirect.com/science/article/pii/S1350453311002761. DOI: 10.1016/j.medengphy.2011.10.011.

3. Wireless sensor network for indoor air quality monitoring / Li J., Murong Li JX, Lai B. et al. - 2014 [Electronic resourse]. - Access mode : http://www.sciencedirect.com/science/article/pii/S1350453311002761. DOI: 10.1016/j.medengphy.2011.10.011.

4. Bartholmai M. Micro-drone for gas measurement in hazardous scenarios via remote sensing / M.Bartholmai, $\begin{array}{llllll}\text { P.Neumann. } & - & 2010 \quad \text { [Electronic } & \text { resource]. }\end{array}$ https://www.researchgate.net/profile/Patrick_Neumann2/publication/263008749_Micro-

Drone_for_Gas_Measurement_in_Hazardous_Scenarios_via_Remote_Sensing/links/54c215310cf25b4b8072d3f5.pdf.

5. Micro-drone for the characterization and self-optimizing search of hazardous gaseous substance sources: A new approach to determine wind speed and direction / P.Neumann, M.Bartholmai, J.H. Schiller et al. // Robotic and Sensors Environments (ROSE). - 2010. - P. 1-6 [Electronic resource]. - Access mode : http://ieeexplore.ieee.org/document/5675265/?reload=true. DOI: 10.1109/rose.2010.5675265.

6. An artificial potential field based sampling strategy for a gas-sensitive micro-drone / P.Neumann S.Asadi, J.H. Schiller et al. // IROS Workshop on Robotics for Environmental Monitoring (WREM). - 2011. - P. 34-38 [Electronic resource]. https://www.researchgate.net/publication/263008583_An_Artificial_Potential_Field_based_Sampling_Strategy_for _a_Gas-Sensitive_Micro-Drone.

7. Gas-drone: Portable gas sensing system on uavs for gas leakage localization / M.Rossi, D.Brunelli, A.Adami et al. // SENSORS. - 2014. - P. 1431-1434 [Electronic resource]. - Access mode : http://ieeexplore.ieee.org/abstract/document/6985282/. DOI: 10.1109/ICSENS.2014.6985282.

8. Autonomous measurement drone for remote dangerous source location mapping / P.Croizé, M.Archez, J.Boisson et al. // International Journal of Environmental Science and Development. - 2015. - Vol. 6 (5) [Electronic resource]. - Access mode : http://www.ijesd.org/vol6/624-T1006.pdf. DOI: 10.7763/IJESD.2015.V6.624.

9. Towards the development of a gas sensor system for monitoring pollutant gases in the low troposphere using small unmanned aerial vehicles / A.Malaver, F.Gonzalez, , A.Depari, et al. // Proceedings of Workshop on Robotics for Environmental Monitoring (Sydney, Australia, 9-13 July 2012) [Electronic resource]. - Access mode : https://eprints.qut.edu.au/52042/.

10. Development and integration of a solar powered unmanned aerial vehicle and a wireless sensor network to monitor greenhouse gases / A.Malaver, N.Motta, P.Corke, F.Gonzalez // Sensors. - 2015. - Vol. 15. - P. 4072-4096 [Electronic resource]. - Access mode : http://www.mdpi.com/1424-8220/15/2/4072/htm. DOI: $10.3390 / \mathrm{s} 150204072$.

11. Коваль А.В. Мобільна бездротова система для аналізу якості повітря / А.В. Коваль, М.С. Гриневич, T.Л. Коваль // Вісник Хмельницького національного університету. - 2019. - № 6. - С. 50-62.

12. Автоматизований двоканальний п’єзоелектричний гравіметр АГС / О.М. Безвесільна, Ю.В. Киричук, Н.М. Назаренко, А.Г. Ткачук // Вісник Хмельницького національного університету. - 2021. - № 2 (295). C. 147-150 [Електронний ресурс]. - Режим доступу : http://journals.khnu.km.ua/vestnik/wpcontent/uploads/2021/08/24.pdf.

\section{References:}

1. Lozano, J., Suárez, J.I., Arroyo, P. et al. (2012), «Wireless sensor network for indoor air quality monitoring», Chemical Engineering, [Online], available http://www.seedengr.com/documents/Wireless\%20Sensor\%20Network\%20For\%20Indoor\%20Air\%20Quality\%20 Monitoring.pdf, doi: 10.3303/CET1230054

2. Tsang-Chu, Yu, Chung-Chih, Lin, Chun-Chang, Chen et al. (2013), «Wireless sensor networks for indoor air quality monitoring», Medical engineering \& physics, Vol. 35 (2), pp. 231-235, [Online], available at: http://www.sciencedirect.com/science/article/pii/S1350453311002761, doi: 10.1016/j.medengphy.2011.10.011.

3. Li, J., Murong, Li JX, Lai, B. et al. (2014), Wireless sensor network for indoor air quality monitoring, [Online], available at: http://www.sciencedirect.com/science/article/pii/S1350453311002761, doi: 10.1016/j.medengphy.2011.10.011.

4. Bartholmai, M. and Neumann, P. (2010), Micro-drone for gas measurement in hazardous scenarios via remote sensing, [Online], available at: https://www.researchgate.net/profile/Patrick_Neumann2/publication/263008749_MicroDrone_for_Gas_Measurement_in_Hazardous_Scenarios_via_Remote_Sensing/links/54c215310cf25b4b8072d3f5.pdf.

5. Neumann, P., Bartholmai, M., Schiller, J.H. et al. (2010), «Micro-drone for the characterization and self-optimizing search of hazardous gaseous substance sources: A new approach to determine wind speed and direction», Robotic and Sensors Environments (ROSE), pp. 1-6, [Online], available at: http://ieeexplore.iee.. rg/document/5675265/?reload=true, doi: $10.1109 /$ rose.2010.5675265.

6. Neumann, P., Asadi, S., Schiller, J.H. et al. (2011), «An artificial potential field based sampling strategy for a gassensitive micro-drone», IROS Workshop on Robotics for Environmental Monitoring (WREM), pp. 34-38, [Online], available at: 
https://www.researchgate.net/publication/263008583_An_Artificial_Potential_Field_based_Sampling_Strategy_for _a_Gas-Sensitive_Micro-Drone

7. Rossi, M., Brunelli, D., Adami, A. et al. (2014), «Gas-drone: Portable gas sensing system on uavs for gas leakage localization», SENSORS, pp. 1431-1434, [Online], available at: http://ieeexplore.ieee.org/abstract/document/6985282/

8. Croizé, P., Archez, M., Boisson, J. et al. (2015), «Autonomous measurement drone for remote dangerous source location mapping», International Journal of Environmental Science and Development, Vol. 6 (5), [Online], available at: http://www.ijesd.org/vol6/624-T1006.pdf

9. Malaver, A., Gonzalez, F., Depari, A., Corke, P. and Motta, N. (2012), «Towards the development of a gas sensor system for monitoring pollutant gases in the low troposphere using small unmanned aerial vehicles», Proceedings of Workshop on Robotics for Environmental Monitoring, Sydney, Australia, 9-13 July 2012.

10. Malaver, A., Motta, N., Corke, P. and Gonzalez, F. (2015), «Development and integration of a solar powered unmanned aerial vehicle and a wireless sensor network to monitor greenhouse gases», Sensors, Vol. 15, pp. 4072 4096, [Online], available at: http://www.mdpi.com/1424-8220/15/2/4072/htm, doi: 10.3390/s150204072.

12. Koval', A.V., Grynevych, M.S. and Koval', T.L. (2019), «Mobil'na bezdrotova systema dlja analizu jakosti povitrja», Visnyk Hmel'nyc'kogo nacional'nogo universytetu, No. 6, pp. 50-62.

13. Bezvesil'na, O.M., Kyrychuk, Ju.V., Nazarenko, N.M. and Tkachuk, A.G. (2021), «Avtomatyzovanyj dvokanal'nyj p'jezoelektrychnyj gravimetr AGS», Visnyk Hmel'nyc'kogo nacional'nogo universytetu, No. 2 (295), pp 147-150 [Online], available at: http://journals.khnu.km.ua/vestnik/wp-content/uploads/2021/08/24.pdf

Ткачук Андрій Геннадійович - кандидат технічних наук, доцент, завідувач кафедри автоматизації та комп'ютерно-інтегрованих технологій ім. проф. Б.Б. Самотокіна Державного університету «Житомирська політехніка».

https://orcid.org/0000-0003-2466-6299.

Наукові інтереси:

- п’єзоелектричні чутливі елементи;

- сучасні інформаційно-вимірювальні системи;

- інтелектуальні мехатронні системи.

Коваль Антон Валерійович - кандидат технічних наук, доцент, доцент кафедри автоматизації та комп'ютерно-інтегрованих технологій ім. проф. Б.Б. Самотокіна Державного університету «Житомирська політехніка».

Наукові інтереси:

- проєктування мобільних роботів;

- безпілотні літальні апарати;

- автоматизовані системи моніторингу забруднення повітря.

Гуменюк Анна Анатоліївна - кандидат технічних наук, доцент, доцент кафедри автоматизації та комп'ютерно-інтегрованих технологій ім. проф. Б.Б. Самотокіна Державного університету «Житомирська політехніка».

http://orcid.org/0000-0002-5744-4599.

Наукові інтереси:

- автоматизовані вимірювальні системи;

- гравіметрія;

- автоматизація проєктування гнучких виробничих систем.

Крижанівська Ілона Володимирівна - кандидат технічних наук, доцент, доцент кафедри автоматизації та комп'ютерно-інтегрованих технологій ім. проф. Б.Б. Самотокіна Державного університету «Житомирська політехніка».

Наукові інтереси:

- сучасні інформаційно-вимірювальні системи;

- автоматизовані вимірювальні системи.

Левчук Володимир Олександрович - магістр спеціальності «Автоматизація та комп’ютерноінтегровані технології» Державного університету «Житомирська політехніка», сертифікований командир зовнішнього екіпажу БпЛА.

Наукові інтереси:

- сучасні інформаційно-вимірювальні системи;

- безпілотні літальні апарати. 